\title{
DESIGN OF CERAMIC-BASED CEMENTS AND PUTTIES FOR BONE GRAFT SUBSTITUTION
}

\author{
Marc Bohner* \\ RMS Foundation, CH-2544 Bettlach, Switzerland
}

\begin{abstract}
In the last 15 years, a large number of commercial ceramicbased cements and putties have been introduced as bone graft substitutes. As a result, large efforts have been made to improve our understanding of the specific properties of these materials, such as injectability, cohesion, setting time (for cements), and in vivo properties. The aim of this manuscript is to summarize our present knowledge in the field. Instead of just looking at scientific aspects, industrial needs are also considered, including mixing and delivery, sterilization, and shelf-life.
\end{abstract}

Keywords: Putty, cement, bone graft substitute, calcium phosphate, injectable.

Note: This article is based on a chapter published in Injectable biomaterials, edited by $\mathrm{B}$. Vernon, published by Woodhead Publishing Limited in 2010 (the original chapter is copyright Woodhead Publishing Limited 2010)

*Address for correspondence:

Marc Bohner

RMS Foundation

Bischmattstrasse 12

CH-2544 Bettlach, Switzerland

Telephone Number: +41326441413

FAX Number: +41326441176

E-mail: marc.bohner@rms-foundation.ch

\section{Introduction}

A few millions patients per year need a bone graft or bone graft substitute to repair a bone defect resulting from an injury or a disease. A large number of bone graft substitutes can be used: unprocessed or processed allogenic bone, animal-derived bone substitutes and synthetic bone substitutes, mostly ceramics (Bauer and Muschler, 2000).

Even though the first studies dealing with ceramic bone substitutes are more than 100 years old (Albee and Morrison, 1920; Dreesmann, 1892), it is only in the 1970s that research soared (Cameron et al., 1977; Hench, 1980; Hulbert et al., 1970; Jarcho et al., 1976; Klawitter and Hulbert, 1971; Nery et al., 1978; Roy and Linnehan, 1974; White et al., 1972). In the early days, studies were mainly focused on porous blocks and granules (Cameron et al., 1977; Hulbert et al., 1970; Klawitter and Hulbert, 1971; Nery et al., 1978; Roy and Linnehan, 1974; White et al., 1972)). However, the discovery of calcium phosphate cements (CPC) in 1982-1983 (Brown and Chow, 1983; LeGeros et al., 1982) opened up a new era in which the handling properties of bone graft substitute became of paramount importance.

Several new approaches have been proposed to improve them. For example, Hanker (Hanker et al., 1986) combined in 1986 Plaster of Paris with calcium phosphate granules to obtain an injectable and setting biphasic paste. In 1987, Klein et al. proposed to mix a sodium alginate solution with $\beta$-tricalcium phosphate ( $\beta$-TCP; $\mathrm{Ca}_{3}\left(\mathrm{PO}_{4}\right)_{2}$; see Table 1) granules $(0.5-1.0 \mathrm{~mm}$ in diameter) to obtain an injectable and hardening paste (hardening of the alginate molecules through crosslinking with $\mathrm{Ca}$ ions) (Klein et al., 1987). Similarly, Gerhart et al. (Gerhart et al., 1988; Gerhart et al., 1989) presented in 1988 a system consisting of gelatine solution, $\beta$-TCP granules $(0.355-$ $0.60 \mathrm{~mm}$ ) and a crosslinker. In the mid 1990s two commercial CPC formulations were introduced (Constantz et al., 1995; Kveton et al., 1995a; Kveton et al., 1995b). These were followed by more than a dozen other commercial CPC formulations (Table 2). Recently, efforts towards composites of hydrogels and bone substitutes (Chan et al., 2002; Chazono et al., 2004; Dupraz et al., 1998; Grimandi et al., 1998; Ito, 1991; Maruyama et al., 1995; Momota et al., 2002; Pompili et al., 1998) have been intensified and several products have been launched (Table 3 ). These efforts are expressed by a rapid increase of the number of publications. For example, a search in "Scopus" (www.scopus.com) using the two keywords "Injectable" and "Ceramic" shows that almost 350 publications were published in 2009 (Fig 1). Combining "Putty" with "Ceramic" leads to a lower number of publications but the evolution is remarkably similar. 


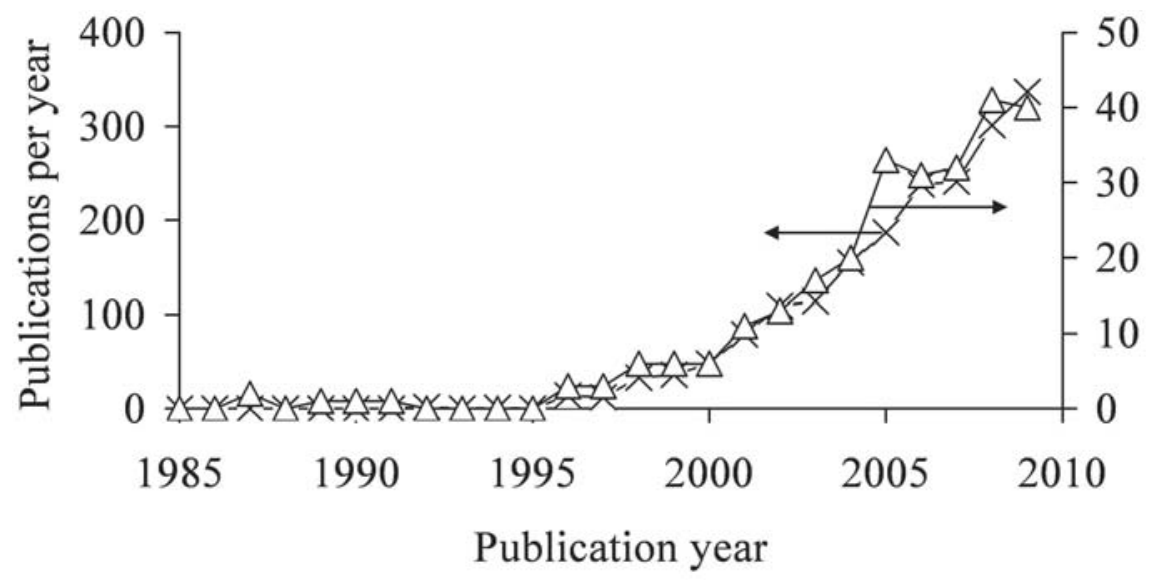

Figure 1: Number of articles cited per year in scopus (www.scopus.com) when selecting the following keywords (search in all fields): (x) "Injectable" and "Ceramic"; ( $\Delta$ ) "Putty" and "Ceramic". State on May 31, 2010.

The aim of this manuscript is to summarize our present knowledge in the field. All types of pasty bone substitutes involving ceramics are considered here. The spectrum goes from non-setting hydrogel-granule putties to CPCs. The term "ceramic" refers generally to non-metallic inorganic materials obtained at high temperature. Here, a broader definition is used since cements are consolidated at or close to room temperature. Therefore, "ceramic" here refers simply to non-metallic inorganic synthetic materials. As a result, all bone-derived pastes are excluded from this manuscript. Importantly, instead of just looking at scientific aspects, such as physico-chemical and biological properties, industrial needs are also considered, including mixing and delivery, sterilization, and shelf-life.

\section{Rheological Properties}

The rheological properties of a bone substitute paste are obviously very important. These include the injectability, the cohesion and the viscosity. Regarding injectability, our understanding has improved markedly in recent years (Bohner and Baroud, 2005; Habib et al., 2008). When a paste which is a biphasic mixture of a finely divided ceramic (powder, granules) and a liquid is submitted to a pressure gradient, the liquid may flow faster than the solid, resulting in local changes of the paste composition. Specifically, the paste present in the region of the highest pressure (e.g., close to the plunger of a syringe) may become so depleted in liquid that the biphasic mixture in this zone is not longer a paste, but a wet powder (Bohner and Baroud, 2005; Habib et al., 2008). Contrarily, the paste in the zone of the lowest pressure (e.g. at the cannula tip) is enriched in liquid. Since these effects are dynamic, the size of the zone depleted in liquid (wet powder) increases during injection, eventually reaching the tip of the injection device and plugging it. This phenomenon is generally referred as filter-pressing, phase separation, or phase migration.

Fortunately, filter-pressing can be reduced or even eliminated by decreasing the particle size of the finely divided solid (powder, granules) (Bohner and Baroud,
2005), using rounder particles (Ishikawa, 2003), using additives to increase the viscosity of the mixing liquid (Andrianjatovo et al., 1995; Bohner and Baroud, 2005), or manipulating the plastic limit and liquid-to-solid ratio (LSR) of the paste (Bohner and Baroud, 2005). Concerning the latter strategy, it has been demonstrated that the injectability increases when the difference between the paste LSR and the plastic limit (minimum amount of liquid to add to a solid to obtain a paste) increases (Bohner and Baroud, 2005). This can be either achieved with an increase of the LSR (Bohner and Baroud, 2005; Burguera et al., 2008), or with a decrease of the plastic limit, for example by adding citrate ions or polyacrylic acid into the mixing liquid (Barralet et al., 2004; Bohner and Baroud, 2005), or by optimizing the particle size distribution of the solid (Gbureck et al., 2005b).

Importantly, there is presently no agreement in the scientific community about the meaning of injectability. For many authors, injectability is a concept related to the force that has to be applied to a syringe in order to inject the paste, independently of the fact that the force is a function of syringe size (Khairoun et al., 1998). A paste is declared non-injectable if the paste cannot be injected with an arbitrary force (generally $100 \mathrm{~N}$ ) using an arbitrary syringe geometry. Another approach is to define the cannula diameter below which the paste cannot be fully injected anymore (Nilsson et al., 2008). This definition is very useful for specific applications such as minimallyinvasive surgery and robocasting, for which the paste has to be injected through very thin cannulae (typically < $0.1 \mathrm{~mm}$ ). In the present document, the injectability is related to the ability of a paste to remain homogeneous under pressure, since phase separation is the cause of filterpressing. So, according to this definition, injectability is still related to a given geometry, but not anymore to a force. In other words, an injectable paste according to the definition used here might be found non-injectable according to the definition of Khairoun et al. (Khairoun et al., 1998).

The second rheological property that should be carefully considered while designing a ceramic bone substitute is the paste cohesion (= cohesiveness, "non- 
Table 1. Main calcium phosphate compounds. The first 6 compounds precipitate at room temperature in aqueous systems. The last 6 compounds are obtained by thermal decomposition or thermal synthesis. The 6 columns contain the name, the corresponding chemical formula, the Ca to P molar ratio, the mineral name, and the typical acronym, respectively. When $x>0$ in the chemical composition of "precipitated hydroxyapatite", one talks also about "calciumdeficient hydroxyapatite" (CDHA). Generally, $\mathrm{x}=1$ so that CDHA has in most cases the composition $\mathrm{Ca}_{9}\left(\mathrm{HPO}_{4}\right)\left(\mathrm{PO}_{4}\right)_{5} \mathrm{OH}$.

\begin{tabular}{|c|c|c|c|c|}
\hline Name & Formula & $\mathrm{Ca} / \mathrm{P}$ & Mineral & Symbol \\
\hline Monocalcium phosphate monohydrate & $\mathrm{Ca}\left(\mathrm{H}_{2} \mathrm{PO}_{4}\right)_{2} \cdot \mathrm{H}_{2} \mathrm{O}$ & 0.50 & - & MCPM \\
\hline Dicalcium phosphate & $\mathrm{CaHPO}_{4}$ & 1.00 & Monetite & DCP \\
\hline Dicalcium phosphate dihydrate & $\mathrm{CaHPO}_{4} \cdot 2 \mathrm{H}_{2} \mathrm{O}$ & 1.00 & Brushite & DCPD \\
\hline Octocalcium phosphate & $\mathrm{Ca}_{8} \mathrm{H}_{2}\left(\mathrm{PO}_{4}\right)_{6} \cdot 5 \mathrm{H}_{2} \mathrm{O}$ & 1.33 & - & $\mathrm{OCP}$ \\
\hline Precipitated hydroxyapatite $^{1}$ & $\mathrm{Ca}_{10-\mathrm{x}}\left(\mathrm{HPO}_{4}\right)_{\mathrm{x}}\left(\mathrm{PO}_{4}\right)_{6-\mathrm{x}}(\mathrm{OH})_{2-\mathrm{x}}$ & $1.33-1.67$ & - & PHA \\
\hline Precipitated amorphous calcium phosphate & $\mathrm{Ca}_{3}\left(\mathrm{PO}_{4}\right)_{2} \cdot \mathrm{nH}_{2} \mathrm{O}$ where $\mathrm{n}=3-4.5 ; 15-20 \% \mathrm{H}_{2} \mathrm{O}$ & 1.50 & - & $\mathrm{ACP}$ \\
\hline Monocalcium phosphate & $\mathrm{Ca}\left(\mathrm{H}_{2} \mathrm{PO}_{4}\right)_{2}$ & 0.50 & - & $\mathrm{MCP}$ \\
\hline$\alpha$-Tricalcium phosphate & $\alpha-\mathrm{Ca}_{3}\left(\mathrm{PO}_{4}\right)_{2}$ & 1.50 & - & $\alpha-$ TCP \\
\hline$\beta$-Tricalcium phosphate & $\beta-\mathrm{Ca}_{3}\left(\mathrm{PO}_{4}\right)_{2}$ & 1.50 & - & $\beta$-ТCР \\
\hline Sintered hydroxyapatite & $\mathrm{Ca}_{10}\left(\mathrm{PO}_{4}\right)_{6}(\mathrm{OH})_{2}$ & 1.67 & Hydroxyapatite & SHA \\
\hline Oxyapatite & $\mathrm{Ca}_{10}\left(\mathrm{PO}_{4}\right)_{6} \mathrm{O}$ & 1.67 & - & OXA \\
\hline Tetracalcium phosphate & $\mathrm{Ca}_{4}\left(\mathrm{PO}_{4}\right)_{2} \mathrm{O}$ & 2.00 & Hilgenstockite & TetCP \\
\hline
\end{tabular}

I (x may vary between 0 and 2 )

decay"). Specifically, it is the ability of the paste to keep its geometrical integrity in an aqueous solution. For a cement, a bad cohesion may prevent setting and may lead to negative in vivo reactions due to the release of microparticles (Miyamoto et al., 1999). Since a high cohesion is the result of strong attractive forces between particles, factors enhancing van der Waals forces (attractive) and decreasing electrostatic forces (repulsive) can be used to improve cohesion. These include a decrease of mean particle size and LSR, and an increase of ionic strength of the mixing solution, (Bohner et al., 2006a). Another approach is to increase the viscosity of the mixing liquid using hydrogels (Andrianjatovo et al., 1995; Bohner et al., 2006a; Cherng et al., 1997). Similarly to cement pastes, it is likely that non-setting pastes consisting of nanoor microparticles (what could be called "mineral suspension") may produce negative biological reactions due to particle release. For pastes consisting of milliparticles ("granules"), a loss of cohesion during implantation may require an intensive washing to remove all loose particles.

So far, relatively little is known about ways to control the viscosity of cement pastes. In fact, to talk about viscosity is an approximation of reality: calcium phosphate pastes are generally non-Newtonian fluids and as a result, the viscosity is a function of shear forces (Baroud et al., 2005). Furthermore, cements have transient properties meaning that the viscosity of a cement paste is a function of shear and time (Liu et al., 2006). Generally, calcium phosphate pastes are thixotropic (shear-thinning) (Baroud et al., 2005; Liu et al., 2006). Both an increase of LSR and an increase of particle size decrease the paste viscosity (Baroud et al., 2005; Liu et al., 2006). Additives are also known to affect viscosity. For example, citrate ions or poly(acrylic acid) decrease the particles interaction and hence decrease viscosity and cohesion (Baroud et al., 2005).

\section{Handling and Delivery}

The handling of a product is of paramount importance for its commercial success. In the case of injectable ceramics, the following aspects have to be carefully looked at: mixing, transfer into a delivery system, and delivery. Besides, the product should be versatile and visible radiologically. These various aspects are discussed hereafter.

There are three categories of products regarding mixing: pre-mixed (= ready-to-use) products (Table 3 ), products that are mixed during delivery (e.g., "VitalOs" in Table 2), and products that have to be mixed prior to use (Tables 2 and 3). Even though pre-mixed products appear very attractive, each of the latter three categories has specific advantages and disadvantages. So, it is important to understand them during the design process of the product. Here is a quick review.

Pre-mixed products are the easiest to use because they do not require any mixing and any transfer into an appropriate delivery system. Moreover, there is no time constraint to use the product once it is open. However, pre-mixing is not a versatile approach to deliver a product since the mixture composition is already pre-defined. Moreover, it is not adapted to CPCs formulations. Presently, only two methods have been proposed to package ready-to-use cement formulations. First, the reactive cement components are combined with a nonaqueous liquid to form a non-reactive pasty mixture (Aberg et al., 2010; Carey et al., 2005). Reaction occurs then in vivo, when the non-aqueous liquid is slowly replaced with physiological fluids. Unfortunately, the setting reaction is difficult to control and the mechanical properties are poor. The second approach is to freeze down the cement components (Grover et al., 2008). However, it is not clear how the storage and handling could be controlled (freezing at $-80^{\circ} \mathrm{C}$ ). Another interesting approach consists of mixing two reactive liquids during their injection by means of a 
Table 2. List of commercial ceramic cements with the producer, product name, composition (when available) and main end-product. The main end-product of the reaction can be either an apatite (calcium-deficient, carbonated, etc...), brushite (= DCPD) or gypsum $\left(\mathrm{CaSO}_{4} \cdot 2 \mathrm{H}_{2} \mathrm{O} ; \mathrm{CSD}\right)$. Denominations: see Table 1 for details.

\begin{tabular}{|c|c|c|c|}
\hline Producer & Product name & Composition & \begin{tabular}{|l|} 
Product \\
\end{tabular} \\
\hline $\begin{array}{l}\text { AG Digital Technology } \\
\text { Corp }\end{array}$ & A-GRIX & $\begin{array}{l}\text { Powder: calcium sulphate hemihydrate powder }\left(\mathrm{CaSO}_{4} \cdot 1 / 2 \mathrm{H}_{2} \mathrm{O} ; \mathrm{CSH}\right) \& \text { calcium sulphate } \\
\text { granules; Solution: Aqueous solution } 1\end{array}$ & Gypsum \\
\hline \multirow{2}{*}{\begin{tabular}{|l|} 
Berkeley Advanced \\
Biomaterials (US)
\end{tabular}} & Cem-Ostetic ${ }^{\mathrm{TM}}$ & Powder: calcium phosphates (details unknown); Solution: Sterile water ${ }^{2}$ & Apatite \\
\hline & Tri-Ostetic $^{\mathrm{TM}}$ & Powder: calcium phosphates (details unknown); Solution: Sterile water ${ }^{2}$ & Apatite \\
\hline Biocomposites Ltd (GB) & Genex $^{(B)}$ & Composition: could not be found ${ }^{1}$ & Gypsum \\
\hline Biomatlante (FR) & MCPC & $\begin{array}{l}\text { Powder: mainly } \alpha \text {-TCP, ACP, BCP = biphasic calcium phosphate (composite between HA } \\
\text { and } \beta \text {-TCP); Solution: phosphate buffered solution (Khairoun et al., 2005) }\end{array}$ & Apatite \\
\hline \multirow{4}{*}{$\begin{array}{l}\text { Biomet (US) } \\
\text { Interpore (US) } \\
\text { Walter Lorenz Surgical } \\
\text { (GER) }\end{array}$} & Calcibon $^{(B)}$ & $\begin{array}{l}\text { Powder: } \alpha \text {-TCP (61\%), DCP (26\%), } \mathrm{CaCO}_{3}(10 \%) \text {, PHA (3\%); Solution: } \mathrm{H}_{2} \mathrm{O}, \mathrm{Na}_{2} \mathrm{HPO}_{4} \\
\text { (Khairoun et al., 1999) }\end{array}$ & Apatite \\
\hline & $\operatorname{Mimix}^{\mathrm{TM}}$ & $\begin{array}{l}\text { Powder: TetCP, } \alpha \text {-TCP, trisodium citrate }\left(\mathrm{C}_{6} \mathrm{H}_{5} \mathrm{O}_{7} \mathrm{Na}_{3} \cdot 2 \mathrm{H}_{2} \mathrm{O}\right) \text {; Solution: } \mathrm{H}_{2} \mathrm{O} \text {, citric acid } \\
\left(\mathrm{C}_{6} \mathrm{H}_{8} \mathrm{O}_{7}\right)^{2}\end{array}$ & Apatite \\
\hline & \begin{tabular}{|l|l|} 
Quick \\
Mimix $^{\mathrm{TM}}$ \\
\end{tabular} & $\begin{array}{l}\text { Powder: Calcium phosphate powders, } \mathrm{Na}_{3} \mathrm{C}_{6} \mathrm{H}_{5} \mathrm{O}_{7} \cdot 2 \mathrm{H}_{2} \mathrm{O} \text {; Solution: Citric acid aqueous } \\
\text { solution }\end{array}$ & Apatite \\
\hline & Bone Plast ${ }^{(R)} \mathrm{QS}$ & Powder: $\mathrm{CSH}\left(\mathrm{CaSO}_{4} \cdot \frac{1}{1} / 2 \mathrm{H}_{2} \mathrm{O}\right)$; Solution: sterile aqueous solution ${ }^{2}$ & Gypsum \\
\hline BoneSupport AB (SWE) & Cerament $^{\mathrm{TM}}$ & $\begin{array}{l}\text { Powder: } \mathrm{CaSO}_{4} \cdot 1 / 2 \mathrm{H}_{2} \mathrm{O}(60 \%) \text {, } \mathrm{HA}(40 \%) \text {; Solution: Aqueous solution of an iodine } \\
\text { radiopacifier (http://www.bonesupport.com/) }\end{array}$ & Gypsum \\
\hline Calcitec (US) & Osteofix & Powder: calcium phosphate and calcium oxide powders; Solution: phosphate buffer ${ }^{2}$ & Apatite \\
\hline \multirow[t]{5}{*}{ ETEX (US) } & $\begin{array}{l}\text { ? -BSM; Embarc; } \\
\text { Biobon }\end{array}$ & $\begin{array}{l}\text { Powder: ACP (50\%), DCPD (50\%); Solution: Unbuffered aqueous saline solution (Lee et al., } \\
\text { 1999; Tofighi et al., 2001) }\end{array}$ & Apatite \\
\hline & $\beta$-BSM & $\begin{array}{l}\text { Composition: could not be found }{ }^{1} \text { (it has apparently a higher compressive strength and better } \\
\text { injectability than } \alpha \text {-BSM) }\end{array}$ & Apatite \\
\hline & $\gamma$-BSM & Composition: could not be found ("putty" consistency) & Apatite \\
\hline & OssiPro & Composition: could not be found $^{1}$; The cement is claimed to be macroporous after hardening ${ }^{2}$ & Apatite \\
\hline & CarriGen & $\begin{array}{l}\text { Composition: synthetic calcium phosphate, sodium carboxymethyl cellulose, sodium } \\
\text { bicarbonate, and sodium carbonate }\end{array}$ & Apatite \\
\hline Futura Biomedical (US) & OsteoCure & Powder: $\mathrm{CaSO}_{4} \cdot 1 / 2 \mathrm{H}_{2} \mathrm{O}$; Solution: sterile mixing solution ${ }^{2}$ & Gypsum \\
\hline \multirow[t]{2}{*}{ Graftys (FR) } & Graftys ${ }^{(B)} \mathrm{HBS}$ & $\begin{array}{l}\text { Powder: mainly ? -TCP, ACP, BCP = biphasic calcium phosphate (composite between HA } \\
\text { and } \beta \text {-TCP); Solution: phosphate buffered solution (Khairoun et al., 2005) }\end{array}$ & Apatite \\
\hline & Graftys ${ }^{\circledR}$ Quickset & $\begin{array}{l}\begin{array}{l}\text { Composition: calcium phosphate salts, hydroxypropylmethylcellulose (HPMC), and } \\
\text { phosphate-based aqueous solution }\end{array}\end{array}$ & Apatite \\
\hline \multirow[t]{2}{*}{ Kasios (FR) } & \begin{tabular}{|l|l} 
Jectos \\
Eurobone $^{\circledR}$
\end{tabular} & $\begin{array}{l}\text { Powder: } \beta \text {-TCP }(98 \%), \mathrm{Na}_{4} \mathrm{P}_{2} \mathrm{O}_{7}(2 \%) ; \text { Solution: } \mathrm{H}_{2} \mathrm{O}, \mathrm{H}_{3} \mathrm{PO}_{4}(3.0 \mathrm{M}), \mathrm{H}_{2} \mathrm{SO}_{4}(0.1 \mathrm{M}) \\
\text { (Frayssinet et al., 2000) }\end{array}$ & Brushite \\
\hline & Jectos + & $\begin{array}{l}\begin{array}{l}\text { Composition: could not be found (likely to be close to that of Jectos) } \\
\text { (http://www.kasios.com/doc-pdf/JECTOS\%2B699ed03-frgb.pdf) }\end{array} \\
\end{array}$ & Brushite \\
\hline Kyphon (US) & KyphOs $^{\mathrm{TM}}$ & $\begin{array}{l}\text { Powder: ? -TCP (77\%), } \mathrm{Mg}_{3}\left(\mathrm{PO}_{4}\right)_{2}(14 \%), \mathrm{MgHPO}_{4}(4.8 \%), \mathrm{SrCO}_{3}(3.6 \%) ; \text { Solution: } \mathrm{H}_{2} \mathrm{O} \text {, } \\
\left(\mathrm{NH}_{4}\right)_{2} \mathrm{HPO}_{4}(3.5 \mathrm{M})(\text { Mulliez and Wenz, 2002) }\end{array}$ & Apatite \\
\hline Lifecore (US) & CalMatrix & Powder: $90 \% \mathrm{CaSO}_{4} \cdot 1 / 2 \mathrm{H}_{2} \mathrm{O}$ and $10 \%$ carboxymethylcellulose; Solution: could not be found ${ }^{2}$ & Gypsum \\
\hline \multirow[t]{2}{*}{ Mitsubishi Materials (J) } & Biopex $^{\circledR}$ & $\begin{array}{l}\text { Powder: } \alpha \text {-TCP }(75 \%) \text {, TetCP }(20-18 \%) \text {, DCPD }(5 \%) \text {, HA }(0-2 \%) \\
\text { Solution: } \mathrm{H}_{2} \mathrm{O} \text {, Sodium succinate }(12-13 \%) \text {, sodium chondroitin sulfate }(5-5.4 \%) \text { (when two } \\
\text { values are indicated, the first value stems from reference (Kurashina et al., 1997) and the } \\
\text { second value from reference (Tanaka et al., 2003)) }\end{array}$ & Apatite \\
\hline & Biopex $^{\circledR}-\mathrm{R}$ & $\begin{array}{l}\text { Powder: } \alpha-\mathrm{TCP}, \mathrm{TetCP}, \mathrm{DCPD}, \mathrm{HA}, \mathrm{Mg}_{3}\left(\mathrm{PO}_{4}\right)_{2}, \mathrm{NaHSO}_{3} \\
\text { Solution: } \mathrm{H}_{2} \mathrm{O} \text {, Sodium succinate, sodium chondroitin sulfate (Tanaka et al., 2003) }\end{array}$ & Apatite \\
\hline Orthogen Corporation & DentoGen & CSH powder and aqueous solution & Gypsum \\
\hline $\begin{array}{l}\text { Produits Dentaires SA } \\
\text { (CH) } \\
\text { CalciphOs }(\mathrm{CH})\end{array}$ & VitalOs $^{4}$ & $\begin{array}{l}\text { Solution 1: } \beta \text {-TCP }(1.34 \mathrm{~g}), \mathrm{Na}_{2} \mathrm{H}_{2} \mathrm{P}_{2} \mathrm{O}_{7}(0.025 \mathrm{~g}), \mathrm{H}_{2} \mathrm{O} \text {, salts }(0.05 \mathrm{M} \mathrm{pH} 7.4 \text { PBS solution); } \\
\text { Solution 2: } \mathrm{MCPM}(0.78 \mathrm{~g}), \mathrm{CaSO}_{4} \cdot 2 \mathrm{H}_{2} \mathrm{O}(0.39 \mathrm{~g}), \mathrm{H}_{2} \mathrm{O}, \mathrm{H}_{3} \mathrm{PO}_{4}(0.05 \mathrm{M}) \text { (Brendlen et al., } \\
\text { 2003) }\end{array}$ & Brushite \\
\hline $\begin{array}{l}\text { Shanghai } \quad \text { Rebone } \\
\text { Biomaterials Co }(\mathrm{CN})\end{array}$ & Rebone & Powder: TetCP, DCP; Solution: $\mathrm{H}_{2} \mathrm{O}$ (Liu et al., 1997) & Apatite \\
\hline \multirow[t]{3}{*}{ Skeletal Kinetics (US) } & Callos $^{\mathrm{TM}}$ & Composition: $\alpha$-TCP, $\mathrm{CaCO}_{3}$, MCPM; Solution: sodium silicate(Constantz, 2002) & Apatite \\
\hline & Callos Inject ${ }^{\mathrm{TM}}$ & $\begin{array}{l}\text { Composition: } \alpha \text {-tricalcium phosphate and unknown compounds (likely to be close to that of } \\
\left.\text { Callos }^{\mathrm{TM}}\right)^{1}\end{array}$ & Apatite \\
\hline & \begin{tabular}{|l|} 
OsteoVation \\
Inject
\end{tabular} & Probably similar to "Callos Inject"T" (Product produced by S.K. but sold by OsteoMed) & Apatite \\
\hline \multirow[t]{2}{*}{$\begin{array}{l}\text { Stryker (US) } \\
\text { Leibinger (GER) }\end{array}$} & BoneSource & $\begin{array}{l}\text { Powder: TetCP (73\%), DCPD (27\%); Solution: } \mathrm{H}_{2} \mathrm{O} \text {, mixture of } \mathrm{Na}_{2} \mathrm{HPO}_{4} \text { and } \mathrm{NaH}_{2} \mathrm{PO}_{4} \\
\text { (Brown and Chow, 1985; Brown and Chow, 1983; Chow, 1991) }\end{array}$ & Apatite \\
\hline & HydroSet $^{\mathrm{TM}}$ & $\begin{array}{l}\text { Powder: TetCP, DCPD, trisodium citrate; Solution: } \mathrm{H}_{2} \mathrm{O} \text {, polyvynilpyrrolidone, sodium } \\
\text { phosphate (Hannink et al., 2008) }\end{array}$ & Apatite \\
\hline \multirow[t]{4}{*}{ Synthes (US) } & \begin{tabular}{|l|} 
Norian \\
Norian ${ }^{\mathbb{B}}$ SRS \\
CRS
\end{tabular} & $\begin{array}{l}\text { Powder: } \alpha \text {-TCP }(85 \%), \mathrm{CaCO}_{3}(12 \%) \text { MCPM (3\%); Solution: } \mathrm{H}_{2} \mathrm{O}, \mathrm{Na}_{2} \mathrm{HPO}_{4}(\text { Constantz et } \\
\text { al., } 1995 ; \text { Fernandez et al., } 1998)\end{array}$ & Apatite \\
\hline & $\begin{array}{l}\text { Norian }{ }^{(\mathbb{R})} \text { SRS Fast } \\
\text { Set Putty } \\
\text { Norian }{ }^{\mathbb{R}} \text { CRS Fast } \\
\text { Set Putty } \\
\end{array}$ & Composition: could not be found (likely to be close to that of Norian SRS/CRS) ${ }^{1}$ & Apatite \\
\hline & Norian Drillable & $\begin{array}{l}\text { Composition: calcium phosphate powder, bioresorbable fibers and sodium hyaluronate } \\
\text { solution }\end{array}$ & Apatite \\
\hline & chronOS $^{\mathrm{TM}}$ Inject & $\begin{array}{l}\text { Powder: } \beta \text {-TCP }(73 \%), \text { MCPM }(21 \%), \mathrm{MgHPO}_{4} \cdot 3 \mathrm{H}_{2} \mathrm{O}(5 \%), \mathrm{MgSO}_{4}(<1 \%), \mathrm{Na}_{2} \mathrm{H}_{2} \mathrm{P}_{2} \mathrm{O}_{7} \\
(<1 \%) \text {; Solution: } \mathrm{H}_{2} \mathrm{O} \text {, sodium hyaluronate }(0.5 \%) \text { (Bohner et al., 2003) }\end{array}$ & Brushite \\
\hline \multirow[t]{2}{*}{ Teknimed (FR) } & Cementek $^{(R)}$ & $\begin{array}{l}\text { Powder: } \alpha \text {-TCP, TetCP, Na Glycerophosphate; Solution: } \mathrm{H}_{2} \mathrm{O}, \mathrm{Ca}(\mathrm{OH})_{2}, \mathrm{H}_{3} \mathrm{PO}_{4} \quad(\mathrm{~S} . \\
\text { Goncalves, Teknimed, private communication) }\end{array}$ & Apatite \\
\hline & Cementek $^{(R)} \mathrm{LV}$ & $\begin{array}{l}\text { Powder: } \alpha \text {-TCP, TetCP, Na Glycerophosphate, dimethylsiloxane; Solution: } \mathrm{H}_{2} \mathrm{O}, \mathrm{Ca}(\mathrm{OH})_{2}, \\
\mathrm{H}_{3} \mathrm{PO}_{4} \text { (S. Goncalves, Teknimed, private communication) }\end{array}$ & Apatite \\
\hline \multirow[t]{4}{*}{ Wright Medical (US) } & $\mathrm{MIIG}^{\mathrm{TM}} 115$ & Powder: CSH; Solution: Saline (Turner et al., 2003) & Gypsum \\
\hline & $\mathrm{MIIG}^{(\mathbb{R})} \mathrm{X} 3$ & Composition: CSH; Solution: Sterile water (contains also traces of an accelerant) & Gypsum \\
\hline & 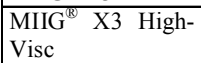 & $\begin{array}{l}\text { Composition: } \mathrm{CSH} \text {; Solution: Sterile water (less than in } \mathrm{MIIG}^{\mathrm{R}} \mathrm{X} 3 \text {; contains also traces of an } \\
\text { accelerant) }\end{array}$ & Gypsum \\
\hline & Pro-Dense ${ }^{(\mathbb{R})}$ & Composition: $75 \% \mathrm{CSH}, 25 \%$ brushite and granular $\beta$-TCP & Gypsum \\
\hline
\end{tabular}

${ }^{1}$ Not found in the literature or on the web

${ }^{2}$ FDA website (http://www.fda.gov/search.ht) - Classification product code: MQV 
Table 3. list of some non-setting non-allogenic pastes with indication of producer, product name, composition and form (pre-mixed or to be mixed). Denominations: $\mathrm{BCP}=$ biphasic calcium phosphate (composite between HA and $\beta$-TCP); CMC = carboxymethylcellulose; HPMC: hydroxypropylmethylcellulose.

\begin{tabular}{|c|c|c|c|}
\hline Producer & Product name & Composition & Form \\
\hline \multirow[t]{2}{*}{ ApaTech (UK) } & Actifuse $^{\mathrm{TM}}$ & HA, polymer and aqueous solution ${ }^{1}$ & Pre-mixed \\
\hline & $\begin{array}{l}\text { Actifuse }^{\mathrm{TM}} \text { Shape } \\
\text { Actifuse }^{\mathrm{TM}} \mathrm{ABX}\end{array}$ & Silicon-substituted calcium phosphate and polymer & Pre-mixed \\
\hline Baxter (US) & $\begin{array}{l}\text { TricOs T } \\
\text { TricOs }\end{array}$ & $\begin{array}{l}\mathrm{BCP}(60 \% \mathrm{HA}, 40 \% \quad \beta-\mathrm{TCP}) \text { granules and Tissucol } \\
\text { (fibrin glue) }{ }^{1}\end{array}$ & To be mixed \\
\hline $\begin{array}{ll}\text { Berkeley } & \text { Advanced } \\
\text { Biomaterials } & \end{array}$ & Bi-Ostetic Putty & Non-disclosed $^{1}$ & $\begin{array}{l}\text { Not } \\
\text { disclosed }^{1}\end{array}$ \\
\hline BioForm (US) & "Calcium hydroxylapatite implant" & $\begin{array}{l}\text { HA powder embedded in a mixture of glycerine, water, } \\
\text { and } \mathrm{CMC}^{1}\end{array}$ & Pre-mixed \\
\hline \multirow[t]{2}{*}{ Biomatlante (FR) } & $\mathrm{MBCP} \mathrm{Gel}^{(R)}$ & $\begin{array}{l}\text { BCP granules ( } 60 \% \text { HA, } 40 \% \beta \text {-TCP; } 0.08-0.2 \mathrm{~mm} \text { ) and } \\
2 \% \text { HPMC (Boix et al., 2006; Gauthier et al., 2005) }\end{array}$ & Pre-mixed \\
\hline & Hydr'Os & $\begin{array}{l}\mathrm{BCP} \text { granules }(60 \% \text { HA, } 40 \% \quad \beta-\mathrm{TCP} ; \text { micro and } \\
\text { nanoparticles) and saline solution (Biomatlante, private } \\
\text { communication) }\end{array}$ & Pre-mixed \\
\hline Degradable solutions $(\mathrm{CH})$ & easy graft $^{\mathrm{TM}}$ & $\begin{array}{l}\beta \text {-TCP or BCP granules }(0.45-1.00 \mathrm{~mm}) \text { coated with } 10 \\
\mu \mathrm{m} \text { PLGA, N-methyl-2-pyrrolydone (K. Ruffieux, } \\
\text { private communication) }\end{array}$ & To be mixed \\
\hline Dentsply (US) & Pepgen $\mathrm{P}-15^{(B)}$ flow & $\begin{array}{l}\text { Hydroxyapatite }(0.25-0.42 \mathrm{~mm}), \text { P-15 peptide and } \\
\text { aqueous sodium hyaluronate solution (product brochure) }\end{array}$ & To be mixed \\
\hline DePuy Spine (US) & Healos $^{(B)} \mathrm{FX}$ & HA $(20-30 \%)$ and collagen ${ }^{1}$ & To be mixed \\
\hline \multirow{2}{*}{ Fluidinova $(\mathrm{P})$} & nanoXIM TCP & $\beta$-TCP (5 or $15 \%)$ and water (company website) & Pre-mixed \\
\hline & nanoXIM HA & HA $(5,15,30$, or $40 \%)$ and water (company website) & Pre-mixed \\
\hline Integra LifeSciences (US) & Mozaik Osteoconductive Scaffold & $\beta$-TCP $(80 \%)$ and type 1 collagen $(20 \%)$ & To be mixed \\
\hline Mathys Ltd $(\mathrm{CH})$ & Ceros $^{(R)}$ Putty / cyclOS ${ }^{(R)}$ Putty & $\begin{array}{l}\beta \text {-TCP granules }(0.125-0.71 \mathrm{~mm} ; 94 \%) \text { and recombinant } \\
\text { sodium hyaluronate powder }(6 \%)\end{array}$ & To be mixed \\
\hline Medtronic (US) & Mastergraft $^{(\circledR)}$ & $\mathrm{BCP}(85 \% \mathrm{HA}, 15 \% \beta$-TCP $)$ and bovine collagen ${ }^{1}$ & To be mixed \\
\hline NovaBone (US) & NovaBone ${ }^{(R)}$ Putty & Bioglass and synthetic binder ${ }^{1}$ & Pre-mixed \\
\hline \multirow[t]{2}{*}{ Orthovita (US) } & Vitoss Flow & $\begin{array}{l}\text { Contains at least bioactive glass and saline solution (or } \\
\text { blood marrow aspirate, or blood) }{ }^{1}\end{array}$ & To be mixed \\
\hline & Vitoss Pack & $\begin{array}{l}\text { Contains at least bioactive glass and saline solution (or } \\
\text { blood marrow aspirate, or blood) }{ }^{1}\end{array}$ & To be mixed \\
\hline Osartis / AAP (GER) & Ostim $^{(B)}$ & $\begin{array}{l}\text { Nanocrystalline HA (35\%) and water (65\%) (Laschke et } \\
\text { al., 2007) }\end{array}$ & Pre-mixed \\
\hline \multirow[t]{2}{*}{ Smith \& Nephew (US) } & JAX CS & $\begin{array}{l}\text { CSD granules and an aqueous solution } \\
\text { (http://global.smith- } \\
\text { nephew.com/us/JAX CS OVERVIEW }\end{array}$ & To be mixed \\
\hline & JAX TCP & $\begin{array}{l}\beta \text {-TCP granules and an aqueous solution of } 1.75 \% \text { CMC } \\
\text { and } 10 \% \text { glycerol (Clarke et al., 2007) }\end{array}$ & To be mixed \\
\hline Stryker (US) & Calstrux $^{\mathrm{TM}}$ & $\beta$-TCP granules and $\mathrm{CMC}^{\mathrm{I}}$ & To be mixed \\
\hline Teknimed (FR) & Nanogel & $\begin{array}{l}\text { Nanocrystalline HA }(100-200 \mathrm{~nm})(30 \%) \text { and water } \\
(70 \%) \text { (S. Goncalves, private communication) }\end{array}$ & Pre-mixed \\
\hline Therics (US) & Therigraft ${ }^{\mathrm{TM}}$ Putty & $\beta$-TCP granules and polymer ${ }^{1}$ & Pre-mixed \\
\hline Zimmer (US) & Collagraft & $\begin{array}{l}\mathrm{BCP} \text { granules }(65 \% \mathrm{HA}, 35 \% \beta-\mathrm{TCP} ; 0.5-1.0 \mathrm{~mm}) \text {, } \\
\text { bovine collagen, and bone marrow aspirate (Bucholz, } \\
2002)\end{array}$ & To be mixed \\
\hline
\end{tabular}

${ }^{1}$ FDA website (http://www.fda.gov/search.html) - Classification product code: MQV

static mixer (Chow and Takagi, 2002; Lemaitre et al., 2003). This approach has more time-constraints than readyto-use putties, but since mixing only occurs in the cannula (= static mixer), the cannula can be changed, for example after cement hardening, and more cement can be injected. However, such an approach is difficult to apply to highlyviscous pastes (leads to syringe plugging). Moreover, it has only been described for brushite CPCs which are much less used than apatite CPCs (Lemaitre et al., 2003) or for a cement paste that contains a non-aqueous water-miscible liquid (Chow and Takagi, 2002). The last and third approach to mix the paste is to combine the powder(s) with the liquid(s) just before use. This approach is more cumbersome, but also more versatile than the two other ones since it allows the addition of various components (e.g. drug solution, platelet-rich plasma, etc...). Moreover, it is generally easier to have the liquid and the solid component as single components during production (e.g., for sterilization - see hereafter). However, as a change of cement composition affects the setting reaction, the modification of the composition by the user is not recommended with setting pastes. To conclude, mixing is not only defined by the possibilities offered by the chemical nature of the product (non-setting or setting paste, composition), but also by the versatility that the producers would like to offer to their costumers, as well as the limitations set by the product manufacturing.

Once implanted, bone graft substitute must be visible by radiological means. Even though ceramic-based products are much more visible than putties based on demineralised bone, there is a need to improve their radiological contrast. So far, three main strategies have been used: (i) add a non-resorbable radiopaque additive such as Tungsten, Tantalum, Bismuth oxide or Barium sulphate particles; (ii) add a resorbable radiopaque additive such as Strontium carbonate as in "Kyphos" product (Table 
2); (iii) add an iodine-based liquid as in "Cerament" product (Table 2). Unfortunately, none of these strategies is very convincing. First, the presence of non-resorbable particles in a resorbable material may eventually lead to the release of billions of particles. Second, strontium carbonate is hardly more radiopaque than calcium phosphates. Finally, iodine-based liquid may cause allergic reactions days after product implantation, with potentially dramatic consequences.

\section{Hardening (for Cements)}

A very important handling property of cements is their hardening rate (= setting rate) because it directly affects the clinical procedure. Specifically, a too early setting reaction limits the period during which the surgeon can apply the cement, whereas a too late setting reaction prevents the surgeon to close the defect and hence extent the overall procedure duration. Generally, the setting rate is characterized by measuring the setting time, i.e. the time it takes to reach a certain mechanical stability, either using a Gillmore needle (ASTM, 1999) or the Vicat test (ASTM, 2002). Unfortunately, the setting time is just one point along the curve relating compressive strength and reaction time. In other words, the setting time does not describe the shape of the curve, e.g. the presence of initial lag, or stepwise versus steady increase. Therefore, various authors have made efforts to not only better characterize the setting reaction but also better understand the factors affecting it (Bohner et al., 2006b; Fukase et al., 1990; Fulmer and Brown, 1990; Ginebra et al., 1999; Hofmann et al., 2006).

A large number of strategies exist to modify the hardening rate of cements, for example, changing the particle size of the reagents, adding a nucleating phase, or dissolving adequate additives (accelerators or retarders) into the mixing solution (Bohner, 2007). So, it is easy to modify the cement composition to reach a setting time that is clinically relevant, typically close to $10 \mathrm{~min}$. Unfortunately, it is more difficult to simultaneously control the initial rate of the reaction and the overall cement reaction (for example to shorten the overall duration of the setting reaction). Therefore, there is potential for improvement and efforts have been focused towards this goal. For instance, it was recently shown that a simple thermal treatment at $500^{\circ} \mathrm{C}$ could extend the initial part of the setting reaction from a few minutes to a few hours hence providing a potential approach to better control the setting reaction (Bohner et al., 2009). In 2007, Brunner et al. demonstrated that nanosized amorphous calcium phosphate particles could be used to produce cements reacting within an hour (Brunner et al., 2007).

\section{Mechanical Properties}

The compressive strength of CPCs and calcium sulphate cements is generally one of the properties presented in scientific publications. It is also often put forward by commercial organizations. Unfortunately, these values are close to be meaningless due to the inherent brittleness of ceramics: the indication of a mean compressive strength of e.g., $50 \mathrm{MPa}$ measured on perfectly-shaped and perfectly-prepared samples (e.g., under vibrations and pressure) does not inform the reader with which probability this cement will fail in situ under a cyclic load of e.g. 10 $\mathrm{MPa}$. The comparison of the compressive strength of the cementious bone substitute with that of cancellous bone is not very helpful either because cancellous bone is much less brittle than ceramic cements. In fact, the reader should get additional information regarding the strength distribution of the cementious material (so-called Weibull distribution (Morgan and Dauskardt, 2003)). Moreover, since loads always contain shear or tensile components, the tensile or the shear properties should also be measured (Charriere et al., 2001). Typically, as result of the material brittleness, the tensile strength is one order of magnitude lower than the compressive strength. Last but not least, loads are generally cyclic, which means that fatigue properties and fracture mechanics are aspects that should also be addressed (Gisep et al., 2004; Morgan and Dauskardt, 2003). When all these measurements are considered, it becomes very clear that CPCs and calcium sulphate cements can only be applied in non-load-bearing applications. The poor mechanical properties of CPCs explain why CPCs are not even performing well in applications where low load-bearing properties are required, for example in bone augmentation (Blattert et al., 2006; Libicher et al., 2006; Libicher et al., 2005; Maestretti et al., 2007; Nakano et al., 2005; Nakano et al., 2002).

Another important aspect to consider when looking at the mechanical properties of cementious bone substitutes is that the mechanical properties may vary quite extensively upon implantation. For example, since gypsum and brushite are soluble in physiological conditions, the mechanical properties of these materials rapidly decrease upon implantation (Ikenaga et al., 1998). This spontaneous dissolution is also the reason why these materials are often combined with less soluble bone substitute such as $\beta$-TCP or HA (Hanker et al., 1986; Ohura et al., 1996; Sato et al., 1998).

\section{Biological Properties}

Since none of the bone substitutes proposed so far in the scientific world are load-bearing or even close to be loadbearing, the main strategy presently used to repair bone defects is to use a bone substitute that is rapidly resorbed and replaced by new mature bone. To reach this goal, not only the chemistry but also the geometry of the bone substitute has to be optimized (Bohner, 2000; Bohner and Baumgart, 2004). For example, it is particularly important to use a bone substitute that can be easily invaded by cells and blood vessels. For that purpose, the bone substitute must have a fully interconnected porous structure with diameters of pores and pore interconnections larger than about 50 $\mu \mathrm{m}$ (Bohner and Baumgart, 2004; Karageorgiou and Kaplan, 2005; Lu et al., 1999; von Doernberg et al., 2006). CPCs are highly porous materials but do not contain 
such macropores (here defined as pores with a diameter larger than $50 \mu \mathrm{m})$. To remedy to this problem, CPC pastes have been combined with highly soluble solids (Barralet et al., 2002; Fernandez et al., 2005; Takagi and Chow, 2001; Xu et al., 2001), hydrophobic liquids (Bohner, 2001), and gas bubbles (Almirall et al., 2004; del Valle et al., 2007; Ginebra et al., 2007; Sarda et al., 2002). Unfortunately, the as-generated macropores are generally not interconnected which limits the extent of this strategy. Another approach to obtain a macroporous pasty bone substitute is to combine granules with a hydrogel, for example sodium alginate (Klein et al., 1987), dextran (Chan et al., 2002), sodium hyaluronate (Chazono et al., 2004), and hydroxypropylmethyl cellulose (Dupraz et al., 1998; Grimandi et al., 1998). Since the solid content of hydrogels is generally very low (a few percents), cells can easily penetrate the hydrogel-filled macroporous gaps present between granules. The size of the macroporous gaps is controlled by the hydrogel fraction and by the granule size distribution.

Another important aspect that should be addressed here is related to the size of the ceramic particles present in the bone substitute paste. It is indeed known that the in vivo response of particular bone substitutes is a function of their dimension and amount (Frank et al., 1991; Pioletti et al., 2000). For example, Evans and Clarke-Smith (Evans and Clarke-Smith, 1991) observed that "only (HA) particles smaller than about $5 \mu \mathrm{m}$ are able to cause damage". So, the biological responses of pastes consisting of loose nano or microsized particles might differ from pastes consisting of mm-large particles. Since it is only recently that products consisting of densely packed but loose particles have been introduced (Tadic and Epple, 2004), there is presently too little in vivo data to really assess the potential risks or benefits associated with loose nano-or microsized particles. Therefore, caution is required when designing a ceramic bone substitute consisting of loose nano- or microsized particles.

In the last decades, there has been a trend towards the use of highly resorbable bone substitutes. Whereas some of these materials, such as $\beta$-TCP, are resorbed by cells, other such as gypsum and brushite are resorbed by simple dissolution. For example, at equilibrium, a solution obtained by dissolving gypsum in water has a calcium concentration roughly 10 times higher than that of serum. Also, serum does not contain sulphate ions. As a result, gypsum dissolution in serum is expected to proceed fairly rapidly. Consequently, gypsum dissolves more rapidly than bone grows leading to the appearance of fibrous tissue in the defect centre (Urban et al., 2003). Compared to gypsum, brushite is one order of magnitude less soluble, but it is still slightly soluble in physiological conditions. So, brushite cements have been shown to rapidly loose their mechanical strength (Ikenaga et al., 1998) and to transform in their centre into an apatite (Bohner et al., 2003; Constantz et al., 1998; Penel et al., 1999). Also, a fibrous gap is observed between ingrowing bone front and resorbing cement front (Apelt et al., 2004; Theiss et al., 2005). However, this gap disappears when only apatite remains in the $\mathrm{CPC}$ block.
In the original CPC formulation proposed by Brown and Chow (Brown and Chow, 1985; Brown and Chow, 1983), no fibrous gap is observed between cement and bone, but physico-chemical changes also occur within the CPC paste due to the fact that the latter formulation sets in basic conditions (Greish and Brown, 2003): apatite precipitates in vivo, hence leading to denser and stronger cements (Ishikawa et al., 1994). As apatite is a basic compound, the precipitation of apatite acidifies the surrounding medium. This is not a problem for an inherently basic cement such as the one proposed by Brown and Chow (Brown and Chow, 1985; Brown and Chow, 1983), but has been thought to provoke negative in vivo reactions when large amounts of brushite cements are implanted (Bohner et al., 2003; Flautre et al., 1999). To conclude, the use of fast resorbable cement may lead to a rapid transformation of a bone defect into mature bone, but bears the risk of negative biological reactions and/or a too fast disappearance leaving an empty defect.

\section{Industrial Design}

When the composition of a bone graft substitute has been optimized to achieve adequate handling, physico-chemical, and biological properties, other problems might arise and render the project unfeasible: non-availability of raw materials, poor product shelf-life, or difficulty to sterilize the product. These aspects are discussed in the next paragraphs.

Whereas in certain fields the specifications of a raw material can be freely chosen, restrictions often exist in the bone graft substitute field due to a small market size. For example, when purchasing calcium phosphates, it is of interest to get a high purity. Unfortunately, most commercially-available calcium phosphates contain impurities in concentrations high enough to cause problems (e.g. Mg content in powders used for $\alpha$-TCP synthesis (Carrodeguas et al., 2008; Enderle et al., 2005)). Whereas the problem might not be too stringent for ceramic raw materials, more problems might arise to purchase polymeric rheological additives. Currently, hyaluronates (acid or salt) have the highest availability among pharmagrade polymer additives. However, hyaluronates are generally sold as unsterile powders and sterilization is complicated (ultra-filtration), particularly for highlyconcentrated solutions $(>3 \%)$. Furthermore, when hyaluronates are sold as solution (e.g. for aesthetic surgery, arthrosis, ophtalmology), the concentration is generally too low (typically $<1 \%$ ) and the volume is either too large $(200-300 \mathrm{~mL})$ or too small $(0.2-1.0 \mathrm{~mL})$. Finally, when all criteria are fulfilled, hyaluronates producers might not be willing to sell the material due to a too small need from the bone graft substitute producers.

Once the product is packaged, it must be sterilized. Unfortunately, polymers and ceramics may require different sterilization methods. For example, most polymers lose their integrity during gamma-sterilization and sometimes also during autoclaving. Alternatively, ceramics are often unstable during autoclaving (e.g. CSD). 
As a result, it might be impossible to find a way to sterilize a ceramic-polymer paste. In the latter case, the only solution is to purchase sterile products and to mix them under aseptic conditions. Unfortunately, as many products cannot be bought sterile and cannot be easily sterilized (e.g., sodium hyaluronate), it might be impossible to produce a product according to its initial design. Instead of offering a one-component product, pre-mixed and ready to be injected to their costumers, companies might have to sell a two-component product that has to be mixed in the operating room.

Once packaged and sterilized, the product must be stable during storage, i.e. during the so-called shelf-life. Obviously, wet pastes are more likely to be unstable than dry mixtures. For example, calcium phosphates may dissolve and precipitate in the solution, leading to a change of the mean crystal/particle size or even to the formation of agglomerates. Since the rheological properties of a paste (e.g. injectability) depend on the mean particle size, rheological properties may be completely altered. Even the stability of dry mixtures is not a trivial problem. For example, Gbureck et al. (Gbureck et al., 2005a) showed that extensive mixing of the dry components of a brushite CPC markedly decreased its shelf-life.

\section{Future Trends}

The last decade has experienced a tremendous change of the bone graft substitute market due to rapidly raising sales: whereas most companies sold only granules and blocks in the 1980s and 1990s, practically all major companies are now offering cements and putties. Furthermore, there is a clear trend towards a specialization of the products: companies are now designing products for specific clinical indications. In other words, the bone graft substitute market has reached a critical size. Since the sales, at least in number, are still rising, this trend will go on in the future.

A particularly strong and recent trend is the introduction of non-setting pastes or putties. Presently, there are as many non-setting pastes as cements. Since their production is often less tricky than that of cements (no need to provide a paste with always the same setting time), and their biological response is often better, it is very likely that there will soon be more commercial formulations of nonsetting pastes than cements. Interestingly, academic research is very limited in this field.

Another important trend in the future will be the improvement of the biological properties of bone substitutes, the aim being to transform a bone defect into new mature bone as fast as possible. This implies that the focus will be set on resorbable materials that possess an open-porous structure allowing cells to invade the structure. Another potential focus could be set on osteoinductive ceramics (Habibovic and de Groot, 2007). A number of authors have indeed observed that ceramic bone graft substitutes implanted under the skin or in muscles are filled or coated with bone over time. However, despite very intensive research, there is only a poor understanding of the mechanisms leading to osteoinduction, and as a result, it is not possible at the moment to design an osteoinductive ceramic.

A last trend is to add minute amounts of foreign ions into ceramic bone graft substitutes to improve their biological behaviour. Most efforts have been set on $\mathrm{Si}$, but other ions have been looked at such as $\mathrm{Mg}, \mathrm{Na}, \mathrm{Sr}$, or Zn (Bigi et al., 1997; Ergun et al., 2002; Gibson et al., 1999; LeGeros et al., 1989; Saint-Jean et al., 2005; Yoshida et al., 2006). Even though effects can be expected, strong scientific evidence is still missing, partly because it is difficult to incorporate foreign ions without modifying other ceramic properties (e.g., solubility, grain size, pore size), and partly because it is difficult to synthesize trulypure ceramics. As a result, it is always difficult or even impossible to know whether the change of biological reaction is due to the release of the investigated ions or to a different factor. A way out of this problem might be to load or coat the bone graft substitutes with soluble salts of the considered ions (Barralet et al., 2009).

\section{Acknowledgment}

Grateful thanks to Y. Bruderer for her help in identifying new commercial products

\section{References}

Aberg J, Brisby H, Henriksson HB, Lindahl A, Thomsen P, Engqvist H (2010) Premixed acidic calcium phosphate cement: Characterization of strength and microstructure. J Biomed Mater Res B Appl Biomater 93: 436-441.

Albee H, Morrison SJ (1920) Studies in bone growth triple calcium phosphate as a stimulus to osteogenesis. Ann Surg 71: 32-39.

Almirall A, Larrecq G, Delgado JA, Martinez S, Planell JA, Ginebra MP (2004) Fabrication of low temperature macroporous hydroxyapatite scaffolds by foaming and hydrolysis of an alpha-TCP paste. Biomaterials 25: 3671 3680.

Andrianjatovo H, Lemaitre J, Deramond H, Duquesnoy B, Hardouin P, Leclet H, Marchandise X (1995) Effects of polysaccharides on the cement properties in the monocalcium phosphate/B-tricalcium phosphate system. Innov Tech Biol Med 16: 140-147.

Apelt D, Theiss F, El-Warrak AO, Zlinszky K, Bettschart-Wolfisberger R, Bohner M, Matter S, Auer JA, von Rechenberg B (2004) In vivo behavior of three different injectable hydraulic calcium phosphate cements. Biomaterials 25: 1439-1451.

ASTM (2002) Standard test Method for time of setting of hydraulic cement by Vicat needle. ASTM Standards C191-01a: 1-6.

ASTM (1999) Standard test method for time of setting of hydraulic-cement paste by Gillmore needles. ASTM Standards C266-99: 1-3.

Baroud G, Cayer E, Bohner M (2005) Rheological characterization of concentrated aqueous B-tricalcium 
phosphate suspensions: The effect of liquid-to-powder ratio, milling time and additives. Acta Biomaterialia 1: $357-$ 363.

Barralet J, Gbureck U, Habibovic P, Vorndran E, Gerard C, Doillon CJ (2009) Angiogenesis in calcium phosphate scaffolds by inorganic copper ion release. Tissue Eng Part A 15: 1601-1609.

Barralet JE, Grover L, Gaunt T, Wright AJ, Gibson IR (2002) Preparation of macroporous calcium phosphate cement tissue engineering scaffold. Biomaterials 23: 30633072.

Barralet JE, Grover LM, Gbureck U (2004) Ionic modification of calcium phosphate cement viscosity. Part I: Hypodermic injection and strength improvement of brushite cement. Biomaterials 25: 2197-2203.

Bauer TW, Muschler GF (2000) Bone graft materials. An overview of the basic science. Clin Orthop 371: 1027.

Bigi A, Foresti E, Gandolfi M, Gazzano M, Roveri N (1997) Isomorphous substitutions in B-tricalcium phosphate: The different effects of zinc and strontium. J Inorg Biochem 66: 259-265.

Blattert TR, Katscher S, Weckbach A (2006) Bone cements in balloon kyphoplasty - Requirements and clinical suitability. Akt Traumatol 36: 18-22.

Bohner M (2000) Calcium orthophosphates in medicine: From ceramics to calcium phosphate cements. Injury 31 Suppl 4: 37-47.

Bohner M (2001) Calcium phosphate emulsions: Possible applications. Key Eng Mater 192-195: 765-768.

Bohner M (2007) Reactivity of calcium phosphate cements. J Mater Chem 17: 3980-3986.

Bohner M, Baroud G (2005) Injectability of calcium phosphate pastes. Biomaterials 26: 1553-1563.

Bohner M, Baumgart F (2004) Theoretical model to determine the effects of geometrical factors on the resorption of calcium phosphate bone substitutes. Biomaterials 25: 3569-3582.

Bohner M, Theiss F, Apelt D, Hirsiger W, Houriet R, Rizzoli G, Gnos E, Frei C, Auer JA, von Rechenberg B (2003) Compositional changes of a dicalcium phosphate dihydrate cement after implantation in sheep. Biomaterials 24: 3463-3474.

Bohner M, Doebelin N, Baroud G (2006a) Theoretical and experimental approach to test the cohesion of calcium phosphate pastes. Eur Cell Mater 12: 26-35.

Bohner M, Malsy AK, Camire CL, Gbureck U (2006b) Combining particle size distribution and isothermal calorimetry data to determine the reaction kinetics of atricalcium phosphate-water mixtures. Acta Biomater 2: 343-348.

Bohner M, Luginbühl R, Reber C, Doebelin N, Baroud G, Conforto E (2009) A physical approach to modify the hydraulic reactivity of $\alpha$-tricalcium phosphate powder. Acta Biomater 5: 3524-3535.

Boix D, Weiss P, Gauthier O, Guicheux J, Bouler JM, Pilet P, Daculsi G, Grimandi G (2006) Injectable bone substitute to preserve alveolar ridge resorption after tooth extraction: A study in dog. J Mater Sci Mater Med 17: 1145-1152.
Brendlen D, Pittet C, Lemaitre J (2003) Feasibility of a new dual-paste presentation of injectable brushite cement. In: Proceedings of the 13th GRIBOI Meeting, Baltimore, MD, USA.

Brown WE, Chow LC (1985) Dental restorative cement pastes. In: US Patent 4'518'430, American Dental Association Health Foundation, USA.

Brown WE, Chow LC (1983) A new calcium phosphate setting cement. J Dental Res 62: 672.

Brunner TJ, Bohner M, Dora C, Gerber C, Stark WJ (2007) Comparison of amorphous TCP nanoparticles to micron-sized alpha-TCP as starting materials for calcium phosphate cements. J Biomed Mater Res B Appl Biomater 83: 400-407.

Bucholz RW (2002) Nonallograft osteoconductive bone graft substitutes. Clin Orthop 395: 44-52.

Burguera EF, Xu HH, Sun L (2008) Injectable calcium phosphate cement: Effects of powder-to-liquid ratio and needle size. J Biomed Mater Res B Appl Biomater 84: 493-502.

Cameron HU, Macnab I, Pilliar RM (1977) Evaluation of a biodegradable ceramic. J Biomed Mater Res 11: 179186.

Carey LE, Xu HH, Simon CG, Jr., Takagi S, Chow LC (2005) Premixed rapid-setting calcium phosphate composites for bone repair. Biomaterials 26: 5002-5014.

Carrodeguas RG, De Aza AH, Turrillas X, Pena P, De Aza S (2008) New approach to the beta-alpha polymorphic transformation in magnesium-substituted tricalcium phosphate and its practical implications. J Am Ceram Soc 91: 1281-1286.

Chan C, Thompson I, Robinson P, Wilson J, Hench L (2002) Evaluation of bioglass/dextran composite as a bone graft substitute. Int J Oral Maxillofac Surg 31: 73-77.

Charriere E, Terrazzoni S, Pittet C, Mordasini PH, Dutoit M, Lemaitre J, Zysset PH (2001) Mechanical characterization of brushite and hydroxyapatite cements. Biomaterials 22: 2937-2945.

Chazono M, Tanaka T, Komaki H, Fujii K (2004) Bone formation and bioresorption after implantation of injectable beta-tricalcium phosphate granules-hyaluronate complex in rabbit bone defects. J Biomed Mater Res 70A: 542549.

Cherng A, Takagi S, Chow LC (1997) Effects of hydroxypropyl methylcellulose and other gelling agents on the handling properties of calcium phosphate cement. J Biomed Mater Res 35: 273-277.

Chow LC (1991) Development of self-setting calcium phosphate cements. J Ceram Soc Jap 99:954-964.

Chow LC, Takagi S (2002) Premixed self-hardening bone graft pastes. In: WO 2004/093734 A2, ADA Foundation, USA.

Clarke SA, Hoskins NL, Jordan GR, Henderson SA, Marsh DR (2007) In vitro testing of advanced JAX bone void filler system: Species differences in the response of bone marrow stromal cells to beta tri-calcium phosphate and carboxymethylcellulose gel. J Mater Sci Mater Med 18: 2283-2290.

Constantz BR (2002) Calcium phosphate cements prepared from silicate solutions. In: US 6'719'993, Skeletal Kinetics, USA. 
Constantz BR, Barr BM, Ison IC, Fulmer MT, Baker J, McKinney L, Goodman SB, Gunasekaren S, Delaney DC, Ross J, Poser RD (1998) Histological, chemical, and crystallographic analysis of four calcium phosphate cements in different rabbit osseous sites. J Biomed Mater Res 43: 451-461.

Constantz BR, Ison IC, Fulmer MT, Poser RD, Smith ST, VanWagoner M, Ross J, Goldstein SA, Jupiter JB, Rosenthal DI (1995) Skeletal repair by in situ formation of the mineral phase of bone. Science 267: 1796-1799.

del Valle S, Miño N, Muñoz F, González A, Planell JA, Ginebra MP (2007) In vivo evaluation of an injectable macroporous calcium phosphate cement. J Mater Sci: Mater Med 18: 353-361.

Dreesmann H (1892) Ueber Knochenplombierung (On bone sealing). Beitr Klin Chir 9: 804-810.

Dupraz A, Delecrin J, Moreau A, Pilet P, Passuti N (1998) Long-term bone response to particulate injectable ceramic. J Biomed Mater Res 42: 368-375.

Enderle R, Gotz-Neunhoeffer F, Gobbels M, Muller FA, Greil P (2005) Influence of magnesium doping on the phase transformation temperature of beta-TCP ceramics examined by Rietveld refinement. Biomaterials 26: 33793384.

Ergun C, Webster TJ, Bizios R, Doremus RH (2002) Hydroxylapatite with substituted magnesium, zinc, cadmium, and yttrium. I. Structure and microstructure. J Biomed Mater Res 59: 305-311.

Evans EJ, Clarke-Smith EMH (1991) Studies on the mechanism of cell damage by finely ground hydroxyapatite particles in vitro. Clin Mater 7: 241-245.

Fernandez E, Planell JA, Best SM, Bonfield W (1998) Synthesis of dahllite through a cement setting reaction. J Mater Sci Mater Med 9: 789-792.

Fernandez E, Vlad MD, Gel MM, Lopez J, Torres R, Cauich JV, Bohner M (2005) Modulation of porosity in apatitic cements by the use of alpha-tricalcium phosphatecalcium sulphate dihydrate mixtures. Biomaterials 26: 3395-3404.

Flautre B, Delecourt C, Blary MC, Van Landuyt P, Lemaitre J, Hardouin P (1999) Volume effect on biological properties of a calcium phosphate hydraulic cement: experimental study in sheep. Bone 25: 35S-39S.

Frank RM, Klewansky P, Hemmerle J, Tenenbaum H (1991) Ultrastructural demonstration of the importance of crystal size of bioceramic powders implanted into human periodontal lesions. J Clin Periodontol 18: 669-680.

Frayssinet P, Roudier M, Lerch A, Ceolin JL, Depres E, Rouquet N (2000) Tissue reaction against a self-setting calcium phosphate cement set in bone or outside the organism. J Mater Sci Mater Med 11: 811-815.

Fukase Y, Eanes ED, Takagi S, Chow LC, Brown WE (1990) Setting reactions and compressive strengths of calcium phosphate cements. J Dent Res 69: 1852-1856.

Fulmer M, Brown PW (1990) The effects of particle size and solution chemistry on the formation of hydroxyapatite. Mat Res Soc Symp Proc 174: 39-44.

Gauthier O, Muller R, von Stechow D, Lamy B, Weiss P, Bouler JM, Aguado E, Daculsi G (2005) In vivo bone regeneration with injectable calcium phosphate biomaterial: a three-dimensional micro-computed tomographic, biomechanical and SEM study. Biomaterials 26: 5444-5453.

Gbureck U, Dembski S, Thull R, Barralet JE (2005a) Factors influencing calcium phosphate cement shelf-life. Biomaterials 26: 3691-3697.

Gbureck U, Spatz K, Thull R, Barralet JE (2005b) Rheological enhancement of mechanically activated alphatricalcium phosphate cements. J Biomed Mater Res B Appl Biomater 73: 1-6.

Gerhart TN, Miller RL, Kleshinski SJ, Hayes WC (1988) In vitro characterization and biomechanical optimization of a biodegradable particulate composite bone cement. J Biomed Mater Res 22: 1071-1082.

Gerhart TN, Renshaw AA, Miller RL, Noecker RJ, Hayes WC (1989) In vivo histologic and biomechanical characterization of a biodegradable particulate composite bone cement. J Biomed Mater Res 23: 1-16.

Gibson IR, Best SM, Bonfield W (1999) Chemical characterization of silicon-substituted hydroxyapatite. J Biomed Mater Res 44: 422-428.

Ginebra MP, Delgado JA, Harr I, Almirall A, Del Valle S, Planell JA (2007) Factors affecting the structure and properties of an injectable self-setting calcium phosphate foam. J Biomed Mater Res 80: 351-361.

Ginebra MP, Fernandez E, Driessens FCM, Planell JA (1999) Modeling of the hydrolysis of alpha-tricalcium phosphate. J Am Ceram Soc 82: 2808-2812.

Gisep A, Kugler S, Wahl D, Rahn B (2004) Mechanical characterisation of a bone defect model filled with ceramic cements. J Mater Sci Mater Med 15: 1065-1071.

Greish YE, Brown PW (2003) Phase evolution during the formation of stoichiometric hydroxyapatite at 37.4 degrees C. J Biomed Mater Res 67B: 632-637.

Grimandi G, Weiss P, Millot F, Daculsi G (1998) In vitro evaluation of a new injectable calcium phosphate material. J Biomed Mater Res 39: 660-666.

Grover LM, Hofmann MP, Gbureck U, Kumarasami B, Barralet JE (2008) Frozen delivery of brushite calcium phosphate cements. Acta Biomaterialia 4: 1916-1923.

Habib M, Baroud G, Gitzhofer F, Bohner M (2008) Mechanisms underlying the limited injectability of hydraulic calcium phosphate paste. Acta Biomater 4: 1465 1471.

Habibovic P, de Groot K (2007) Osteoinductive biomaterials - Properties and relevance in bone repair. $\mathrm{J}$ Tissue Eng Regen Med 1: 25-32.

Hanker JS, Terry BC, Ambrose WW, Lupton CR (1986) Plaster of Paris as a bioresorbable scaffold in implants for bone repair. In: US Patent 4'619'655, University of North Carolina, USA.

Hannink G, Wolke JGC, Schreurs BW, Buma P (2008) In vivo behavior of a novel injectable calcium phosphate cement compared with two other commercially available calcium phosphate cements. J Biomed Mater Res - Part B Applied Biomaterials 85:478-488.

Hench LL (1980) Biomaterials. Science 208: 826-831. Hofmann MP, Young AM, Gbureck U, Nazhat SN, Barralet JE (2006) FTIR-monitoring of a fast setting brushite bone cement: effect of intermediate phases. J Mater Chem 16: 3199-3206. 
Hulbert SF, Young FA, Mathews RS, Klawitter JJ, Talbert CD, Stelling FH (1970) Potential of ceramic materials as permanently implantable skeletal prostheses. J Biomed Mater Res 4: 433-456.

Ikenaga M, Hardouin P, Lemaitre J, Andrianjatovo H, Flautre B (1998) Biomechanical characterization of a biodegradable calcium phosphate hydraulic cement: a comparison with porous biphasic calcium phosphate ceramics. J Biomed Mater Res 40: 139-144.

Ishikawa K (2003) Effects of spherical tetracalcium phosphate on injectability and basic properties of apatitic cement. Key Eng Mater 240-2: 369-372.

Ishikawa K, Takagi S, Chow LC, Ishikawa Y, Eanes ED, Asaoka K (1994) Behavior of a calcium phosphate cement in simulated blood plasma in vitro. Dent Mater 10: $26-32$.

Ito M (1991) In vitro properties of a chitosan-bonded hydroxyapatite bone-filling paste. Biomaterials 12: 41-45. Jarcho M, Bolen CH, Thomas MB, Bobick J, Kay JF, Doremus RH (1976) Hydroxylapatite synthesis and characterization in dense polycrystalline form. J Mater Sci Lett 11: 2027-2035.

Karageorgiou V, Kaplan D (2005) Porosity of 3D biomaterial scaffolds and osteogenesis. Biomaterials 26: 5474-5491.

Khairoun I, Boltong MG, Driessens FCM, Planell JA (1998) Some factors controlling the injectability of calcium phosphate bone cements. J Mater Sci Mater Med 9: 425428.

Khairoun I, Driessens FC, Boltong MG, Planell JA, Wenz R (1999) Addition of cohesion promotors to calcium phosphate cements. Biomaterials 20: 393-398.

Khairoun I, LeGeros RZ, Daculsi G, Bouler JM, Guicheux G, Gauthier O (2005) Macroporous, resorbable and injectible calcium phosphate-based cements (MCPC) for bone repair, augmentation, regeneration, and osteoporosis treatment. In: US Patent 7'351'280 B2, New York University and Université de Nantes, USA \& France.

Klawitter JJ, Hulbert SF (1971) Application of porous ceramics for the attachment of load bearing internal orthopedic applications. J Biomed Mater Res Symp 2: 161229.

Klein CP, van der Lubbe HB, de Groot K (1987) A plastic composite of alginate with calcium phosphate granulate as implant material: an in vivo study. Biomaterials 8: $308-310$.

Kurashina K, Kurita H, Hirano M, Kotani A, Klein CP, de Groot K (1997) In vivo study of calcium phosphate cements: Implantation of an alpha-tricalcium phosphate/ dicalcium phosphate dibasic/tetracalcium phosphate monoxide cement paste. Biomaterials 18: 539-543.

Kveton JF, Friedman CD, Costantino PD (1995a) Indications for hydroxyapatite cement reconstruction in lateral skull base surgery. Am J Otol 160: 465-469.

Kveton JF, Friedman CD, Piepmeier JM, Costantino PD (1995b) Reconstruction of suboccipital craniectomy defects with hydroxyapatite cement: a preliminary report. Laryngoscope 105: 156-159.

Laschke MW, Witt K, Pohlemann T, Menger MD (2007) Injectable nanocrystalline hydroxyapatite paste for bone substitution: in vivo analysis of biocompatibility and vascularization. J Biomed Mater Res B Appl Biomater 82: 494-505.

Lee DD, Tofighi A, Aiolova M, Chakravarthy P, Catalano A, Majahad A, Knaack D (1999) Alpha-BSM: a biomimetic bone substitute and drug delivery vehicle. Clin Orthop 367 Suppl: S396-405.

LeGeros RZ, Chohayeb A, Shulman A (1982) Apatitic calcium phosphates: possible dental restorative materials. J Dent Res 61: 343.

LeGeros RZ, Daculsi G, Kijkowska R, Kerebel B, Ed YI, J D, John LCl (1989) The effect of magnesium on the formation of apatites and whitlockites. In: Magnesium in Health and Disease (Itokawa Y, Durlach J, eds), John Libbey Eurotext, Montrouge, France, pp. 11-19.

Lemaitre J, Pittet C, Brendlen D (2003) Pasty or liquid multiple constituent compositions for injectable calcium phosphate cements. In: WO 03/041753 A1.

Libicher M, Hillmeier J, Liegibel U, Sommer U, Pyerin W, Vetter M, Meinzer HP, Grafe I, Meeder P, Noldge G, Nawroth P, Kasperk C (2006) Osseous integration of calcium phosphate in osteoporotic vertebral fractures after kyphoplasty: Initial results from a clinical and experimental pilot study. Osteoporos Int 17: 1208-1215.

Libicher M, Vetter M, Wolf I, Noeldge G, Kasperk C, Grafe I, Da Fonseca K, Hillmeier J, Meeder PJ, Meinzer HP, Kauffmann GW (2005) Ct volumetry of intravertebral cement after kyphoplasty. Comparison of polymethylmethacrylate and calcium phosphate in a 12month follow-up. Eur Radiol 15: 1544-1549.

Liu C, Shao H, Chen F, Zheng H (2006) Rheological properties of concentrated aqueous injectable calcium phosphate cement slurry. Biomaterials 27: 5003-5013.

Liu C, Shen W, Gu Y, Hu L (1997) Mechanism of the hardening process for a hydroxyapatite cement. J Biomed Mater Res 35: 75-80.

Lu JX, Flautre B, Anselme K, Hardouin P, Gallur A, Descamps M, Thierry B (1999) Role of interconnections in porous bioceramics on bone recolonization in vitro and in vivo. J Mater Sci-Mater Med 10: 111-120.

Maestretti G, Cremer C, Otten P, Jakob RP (2007) Prospective study of standalone balloon kyphoplasty with calcium phosphate cement augmentation in traumatic fractures. Eur Spine J 16: 601-610.

Maruyama M, Terayama K, Ito M, Takei T, Kitagawa E (1995) Hydroxyapatite clay for gap filling and adequate bone ingrowth. J Biomed Mater Res 29: 329-336.

Miyamoto Y, Ishikawa K, Takechi M, Toh T, Yuasa T, Nagayama M, Suzuki K (1999) Histological and compositional evaluations of three types of calcium phosphate cements when implanted in subcutaneous tissue immediately after mixing. J Biomed Mater Res 48: 36-42.

Momota Y, Miyamoto Y, Ishikawa K, Takechi M, Yuasa T, Tatehara S, Nagayama M, Suzuki K (2002) Evaluation of feasibility of hydroxyapatite putty as a local hemostatic agent for bone. J Biomed Mater Res 63: 542-547.

Morgan JP, Dauskardt RH (2003) Notch strength insensitivity of self-setting hydroxyapatite bone cements. J Mater Sci-Mater Med 14: 647-653.

Mulliez MA, Wenz R (2002) Physical-chemical characterization of a new magnesium containing calcium phosphate cement soprim. In: Proceedings of the European 
Society for Biomaterials Annual Meeting (ESB 2002), Barcelona.

Nakano M, Hirano N, Ishihara H, Kawaguchi Y, Matsuura K (2005) Calcium phosphate cement leakage after percutaneous vertebroplasty for osteoporotic vertebral fractures: Risk factor analysis for cement leakage. J Neurosurg Spine 2: 27-33.

Nakano M, Hirano N, Matsuura K, Watanabe H, Kitagawa H, Ishihara H, Kawaguchi Y (2002) Percutaneous transpedicular vertebroplasty with calcium phosphate cement in the treatment of osteoporotic vertebral compression and burst fractures. J Neurosurg 97: 287-293.

Nery EB, Lynch KL, Rooney GE (1978) Alveolar ridge augmentation with tricalcium phosphate ceramic. J Prosthet Dent 40: 668-675.

Nilsson M, Liden E, Ehrenborg C, Forsgren J, Jönsson SA (2008) What is injectability? A new injectability method for hydraulic cements developed for minimally invasive surgery. In: Proceedings of the $18^{\text {th }}$ GRIBOI Meeting, Montreal, pp 51.

Ohura K, Bohner M, Hardouin P, Lemaitre J, Pasquier G, Flautre B (1996) Resorption of, and bone formation from, new beta-tricalcium phosphate-monocalcium phosphate cements: an in vivo study. J Biomed Mater Res 30: 193-200.

Penel G, Leroy N, Van Landuyt P, Flautre B, Hardouin P, Lemaitre J, Leroy G (1999) Raman microspectrometry studies of brushite cement: in vivo evolution in a sheep model. Bone 25: 81S-84S.

Pioletti DP, Takei H, Lin T, Van Landuyt P, Ma QJ, Kwon SY, Sung KL (2000) The effects of calcium phosphate cement particles on osteoblast functions. Biomaterials 21: 1103-1114.

Pompili A, Caroli F, Carpanese L, Caterino M, Raus L, Sestili G, Occhipinti E (1998) Cranioplasty performed with a new osteoconductive osteoinducing hydroxyapatitederived material. J Neurosurg 89: 236-242.

Roy DM, Linnehan SK (1974) Hydroxyapatite formed from coral skeletal carbonate by hydrothermal exchange. Nature 247: 220-222.

Saint-Jean SJ, Camire CL, Nevsten P, Hansen S, Ginebra MP (2005) Study of the reactivity and in vitro bioactivity of Sr-substituted alpha-TCP cements. J Mater Sci Mater Med 16: 993-1001.

Sarda S, Fernandez E, Nilsson M, Planell JA (2002) Influence of air-entraining agent on bone cement macroporosity. Key Eng Mat 218-2: 335-338.
Sato S, Koshino T, Saito T (1998) Osteogenic response of rabbit tibia to hydroxyapatite particle-plaster of Paris mixture. Biomaterials 19: 1895-1900.

Tadic D, Epple M (2004) A thorough physicochemical characterisation of 14-calcium phosphate-based bone substitution materials in comparison to natural bone. Biomaterials 25: 987-994.

Takagi S, Chow LC (2001) Formation of macropores in calcium phosphate cement implants. J Mater Sci-Mater M 12: 135-139.

Tanaka S, Kishi T, Shimogoryo R, Matsuya S, Ishikawa K (2003) Biopex acquires anti-washout properties by adding sodium alginate into its liquid phase. Dent Mater J 22: 301-312.

Theiss F, Apelt D, Brand B, Kutter A, Zlinszky K, Bohner M, Matter S, Frei C, Auer JA, von Rechenberg B (2005) Biocompatibility and resorption of a brushite calcium phosphate cement. Biomaterials 26: 4383-4394.

Tofighi A, Mounic S, Chakravarthy P, Rey C, Lee D (2001) Setting reactions involved in injectable cements based on amorphous calcium phosphate. Key Eng Mater 192-195: 769-772.

Turner TM, Urban RM, Gitelis S, Haggard WO, Richelsoph K (2003) Resorption evaluation of a large bolus of calcium sulfate in a canine medullary defect. Orthop 26: s577-579.

Urban RM, Turner TM, Hall DJ, Infanger S, Cheema N, Lim TH (2003) Healing of large defects treated with calcium sulfate pellets containing demineralized bone matrix particles. Orthop 26: s581-585.

von Doernberg MC, von Rechenberg B, Bohner M, Grunenfelder S, van Lenthe GH, Muller R, Gasser B, Mathys R, Baroud G, Auer J (2006) In vivo behavior of calcium phosphate scaffolds with four different pore sizes. Biomaterials 27: 5186-5198.

White RA, Weber JN, White EW (1972) Replamineform: a new process for preparing porous ceramic, metal, and polymer prosthetic materials. Science 176: $922-924$.

Xu HH, Quinn JB, Takagi S, Chow LC, Eichmiller FC (2001) Strong and macroporous calcium phosphate cement: effects of porosity and fiber reinforcement on mechanical properties. J Biomed Mater Res 57: 457-466.

Yoshida K, Hyuga H, Kondo N, Kita H, Sasaki M, Mitamura M, Hashimoto K, Toda Y (2006) Substitution model of monovalent ( $\mathrm{Li}, \mathrm{Na}$, and $\mathrm{K}$ ), divalent $(\mathrm{Mg})$, and trivalent (Al) metal ions for $\hat{\mathrm{I}}^{2}$-tricalcium phosphate. J Am Ceram Soc 89: 688-690. 